\title{
STEFFENSEN TYPE INEQUALITIES INVOLVING CONVEX FUNCTIONS
}

\author{
Josip PEČARIĆ AND KSENIJA SMOLJAK
}

Abstract. In this paper a new class of functions $\mathscr{M}_{1}^{c}[a, b]$ that extends the class of convex functions is introduced. Moreover, Steffensen type inequalities for the class of convex functions are proved as a consequence of more general inequalities for class $\mathscr{M}_{1}^{c}[a, b]$. Using the linear functionals constructed from the difference of the left and the right hand side of proved Steffensen type inequalities new families of exponentially convex functions and related results are obtained.

Mathematics subject classification (2010): 26D15, 26A51.

Keywords and phrases: Steffensen inequality, weaker conditions, convex function, exponential convexity.

\section{REFERENCES}

[1] S. N. Bernstein, Sur les fonctions absolument monotones, Acta Math. 52 (1929), 1-66.

[2] J. JAKŠETIĆ AND J. PEČARIĆ, Exponential convexity method, J. Convex Anal. 20 (1) (2013), 181 197.

[3] G. Milovanović And J. PeČARIĆ, The Steffensen inequality for convex function of order $n$, Univ. Beograd. Publ. Elektrotehn. Fak. Ser. Mat. Fiz. 634-677 (1979), 97-100.

[4] D. S. Mitrinović AND P. M. VAsić, Analytic Inequalities, Springer-Verlag, Berlin-Heidelberg-New York, 1970.

[5] D. S. Mitrinović, J. E. PeČArić And A. M. Fink, Classical and new Inequalities in analysis, Kluwer Academic Publishers, The Netherlands, 1993.

[6] J. PeČARIĆ, A. PeruŠić AND K. SMOlJaK, Mercer and Wu-Srivastava generalisations of Steffensen's inequality, Appl. Math. Comput. 219 (21) (2013), 10548-10558.

[7] J. E. PeČarić, F. Proschan And Y. L. Tong, Convex functions, partial orderings, and statistical applications, Academic Press, San Diego, 1992.

[8] J. F. STEFFENSEN, On certain inequalities between mean values and their application to actuarial problems, Skand. Aktuarietids. (1918), 82-97.

[9] P. VASIĆ AND J. PeČARIĆ, Note on the Steffensen inequality, Univ. Beograd. Publ. Elektrotehn. Fak. Ser. Mat. Fiz. 716-734 (1981), 80-82. 